\title{
The Perceptions of Information Literacy by Students in English Language Departments: A Comparative Study
}

\author{
Irfan Tosuncuoglu ${ }^{1, *} \&$ Halil Küçükler ${ }^{2}$ \\ ${ }^{1}$ Department of English Language and Literature, Karabük University, Karabük, Turkey \\ ${ }^{2}$ School of Foreign Languages, Balıkesir University, Balıkesir, Turkey \\ *Correspondence: Department of English Language and Literature, Karabük University, 78050 Karabük, Turkey. Tel: \\ 90-370-418-7800. E-mail: irtosun@yahoo.com
}

Received: January 4, 2019

doi:10.5430/wje.v9n1p125
Accepted: January 26, 2019 Online Published: February 14, 2019

URL: https://doi.org/10.5430/wje.v9n1p125

\begin{abstract}
Information literacy is a fundamental component of the educational process. One of the most essential considerations involved in the course of providing effective education to students, is the need to instil in them the need to be aware of the information and facts that most impact their own lives and the societies in which they live. Information literacy includes accessing the essential pieces of information that are necessary for the purpose of functioning as a fully informed adult in a democratic society. When these statements are considered within the scope of education and foreign or second language teaching, it is apparent that teachers need to be information literates since they are the ones who transfer information or show the way towards it. In order to find out the Information literacy levels of the students of two state universities in Turkey, a survey was conducted in the study. The participants were the students of the English Language and Literature departments of these universities. As one of universities prefers to remain anonymous, we called them University 1 and 2 in the study. University 1 had 50 participants and University 2 had 47, so there were a total of 97 participants in the survey. Descriptive research design was used in this research. The two universities were compared, from the point of view of information literacy awareness in the study, and some differences were found. For further studies, many more universities can be included in order to obtain a more general and common conclusions.
\end{abstract}

Keywords: English language department, information literacy, technology, internet

\section{Introduction}

Education once more entered a process of renewal after the industrial revolution, which made a massive impact on history and especially in the years following the World War II, in conjunction with technological developments. The rapid changes and developments, international competition and the dissipation of the significance of international boundaries kick-started a cumulative increase in the importance of information together with information and communication technology. So much so, that individuals who possess information, and are therefore the source, are considered powerful. The age that we inhabit is called the Information Age, while the societies which inhabit this age are called Information Societies.

As for the concept of information literacy, it was first used by Paul Zurkowski in 1974 (Uzuegbu, 2014). According to him, people who are information literates are those who can utilise sources of information. In other words, the abilities that are required by information literates are expressed by Zurkowski as individuals who have the ability to access information through a diverse range of sources and tools. Doyle (1994) and Wilkinson (2012) describe these abilities as comprehension that the right information is effective on decision-making, being aware of the need for information, accessing sources of information, being able to use computers and other technologies, evaluating information, organising information and being able to utilise information in problem-solving.

Principally following the second half of the 20th century, developments taking place in the information and communication technologies have affected the systems oriented towards the processing, storage, access and transmission of information; different tools, methods and concepts (audio-visual tools, data-communication, digital information sources, databases, networks etc.) have come to the forefront (Breivik \& Senn, 1998; Kurbanoğlu \& 
Akkoyunlu, 2001; UNESCO/United Nations Educational, Scientific and Cultural Organisation, 2006). This state of affairs made it necessary for information to be presented on digital platforms alongside published mediums. Information literates have the ability to obtain information when needed, to evaluate it and to be able to both use it and transmit it to others (Kurbanoğlu \& Akkoyunlu, 2004).

When these statements are considered within the scope of education and foreign or second language teaching, it is apparent that teachers need to be information literates since they are the ones who transfer information to learners or illuminate the way towards it. If they are able to effectively utilise digital technology and the internet, this shows that they are at an adequate level of teaching by means of technology.

\section{Theoretical Background}

In the 21 st century, it is anticipated that individuals will attain the following characteristics (European Communities, 2006; Larson \& Marsh, 2005; Önal \& Alaca, 2017). Actively speaking and writing in the native language; Reading and understanding all kinds of informative technical and prose texts; The ability to use arithmetic for evaluation correctly; The possession of important and fundamental global information on geography, history, local and national political and cultural structures; Competence in arts, humanities, sciences and technology; Proficiency in at least one practical skill (playing an instrument, developing handcraft etc.); Reading and writing in a foreign language; The desire to acquire information on their interests in and new ideas and thoughts; Forming the habit of critically evaluating information; The cultural awareness necessary to find and evaluate information using traditional and modern techniques; Developing the skills of using information and communication technology; Using information and skills pertaining to citizenship.

Previous studies have been conducted in order to determine the information requirements and information inquisitive behaviour of young people of school age. The changing conditions and technology development also affect education systems, information requirements, information services and information sources. There must me novelties in the field of classical education process. Motivation is also important factor as Aydın (2010), Glasser (1996) and Wlodowski (1999) stated that motivation had great importance in terms of reaching the educational goals. For the teachers, educational information technology is the basic and core course rather than an additional requirement. The information services to be provided has been considered within the framework of these changes (Kavuncu, 2001; Uçak \& Topçu, 2012; Alaca \& Önal, 2017; Yan-xia, 2017; Öztürk \& Tağa, 2018).

Akkoyunlu and Korkut (2008), studied the self-efficacy pertaining to the information literacy of foreign language teacher candidates. In the study, self-efficacy of information, computer literacy and perceptions of the self-efficacy of information and computer literacy were analysed on the basis of class level and gender.

Within the Turkish context, the widest area of application of the use of information technology within the educational environment of secondary education, we encountered the FATIH project in 2010 (Yavuzalp et al., 2015), and in teaching foreign languages we observe the computer assisted language teaching system DynEd English Language System. However, as a result of the studies conducted, an important issue was acknowledged, namely that students only improved their basic computing skills and that branch teachers (who teach major subjects such as English and maths, etc.) were unaware of how they could integrate technology into their classes (Eğitim Reformu Girişim, 2013).

\section{The Situation of the Teachers}

On the other hand, it is known that education lies at the base of many societal problems in Turkey and that these problems are becoming ever more complex. Teachers are a paramount element of education, and training a competent and well-qualified teacher is an issue. It should not be forgotten that good education can be provided with good teachers, while creditable education can only be provided by virtue of qualified teachers (Çelikten, Şanal, \& Yeni, 2005). Another issue that teachers face is their effectiveness in the face of the information society. This situation can be triggered by many variables, including individual and professional ones.

While students, schools and hence society, occupy the centre of developmental plans and technological policies, it should not be forgotten that those who will play an important part in the process of goals becoming reality are the teachers. The difficulties faced by teachers and their feeling of inadequacy can be compensated for by effective in-service training and increasing levels of information literacy. In this way, it might be possible for the policies to be carried into effect and the society to be developed (Avc1 \& Seferoğlu, 2011, p. 19-20). In this vein, some researchers (Etta \& Elder, 2005; Qin \& He, 2009) stated that: English teachers who have good information literacy level are able 
to integrate information technology into English teaching process effectively, create authentic, fruitful and meaningful learning environments.

Many problems such as teacher training, employment and personal rights are being expressed in all kinds of environments and scientific studies in which the Turkish education system is discussed. Despite the fact that teacher issues are one of the oldest and the most deep-rooted problems of the Turkish education system, it can be seen that it does not exhibit a great difference from the current problems, and the conduct of effective applications oriented towards resolving these issues are insufficient (Demir \& Arı, 2013). In this vein, Aydın (2016) and Irgatoğlu (2018), states that another problematic area of foreign language teacher training programs of our age is that our teachers prove deficient in following and applying special interest areas as well as in technological, professional and methodological development, so this teacher education is getting important all the more at universities in order to meet the requirements of the instructors to follow the latest developments and innovations.

\section{Problem and Expectations}

Rapidly developing technology has increased the amount of information that is produced and as a consequence, individuals have become addicted to information by virtue of this information overload. Developments in information and communication technology have globalised the world by providing easier information access and processing. That technology is in a state of rapid change and development has shown itself within the educational field, causing changes in the information and skills that individuals need to possess. What is expected of educational institutions is that they train individuals who can actively use technology as well as those who can access, process and communicate information. Since it has become imperative that individuals accommodate developments, the requirement has arisen for them to possess the necessary self-efficacy. While information is an important factor for technological and scientific development, it is a resource that bears vital significance for world economies, and is the most fundamental factor in education. For this reason, according to Akkoyunlu (2008), information is the most fundamental asset in the information age in which we live. Individuals first need to learn how to access information in order for them to use it in the processes of producing, consuming and processing information. Furthermore, in order for individuals to be successful in their personal, professional and academic lives, they need to be able to creatively use technology in learning and problem solving, and to possess communication and critical thinking skills.

It is emphasized that the concept of information literacy should have a place in all levels of educational programs, beginning from the level of primary education (Akkoyunlu \& Kurbanoğlu, 2002; Carr, 1998). In order for these developments to occur, not only the students but the teachers who are to lead them, are expected to be information literates.

In these modern times, it is necessary for individuals to be able to actively utilise information and communication technology in order for them to be relevant information literates. Information and communication technology is defined as the internet, e-mail and multimedia which encompass computer-based technology (Lowe \& McAuley, 2000, p.6).

When viewed from this aspect, it is expected that university students along with the teachers who educate them need to be information literate individuals who use information and communication technologies to the maximum level. The integration of information technology and English language teaching has been very popular. On the basis of the importance of information literate individuals for today and the fact that there are not enough studies on this subject especially in English teaching in Turkey, this study aims to examine the perceptions of the information literacy of students receiving English language education in two state universities who expect to become English Teachers in the future, taking miscellaneous variables into account. The resulting data, defined whether there is the inadequacy in the related issue.

\section{Method}

\subsection{Research Design}

Descriptive research design was used in this research and this was a quantitative study. This research design denotes a study designed in order to describe the target population. It requires collecting quantitative information. That is to say, that means collecting data that describes the situation under investigation and then organises, and describes the issue. The data collected was mainly descriptive data. The research approach to the survey was utilised to collect data from the participant population. The study was sampled in a standard way. In this type of research, the sample is randomly verified from a pre-determined list. In addition, the point to consider here is that the factors in the list 
created, consist of similar features such as age, level, etc., as Çepni (2007), refers.

\subsection{Participants}

The research was fulfilled in the 2018-2019 academic year by students of two different State universities in Turkey. Both universities are situated in the developing regions and in moderate sized cities. And in both universities, it was compulsory for students to complete an English Preparatory Program successfully, attending for 8-9 months before proceeding to the four-year studies in their departments. The participants were the students of the English Language and Literature departments of these universities. There were 21 males and 76 females whose ages were between 18-30. They studied in both Daytime (69 students) and Evening (28 students) Education. University 1 had 50 participants and University 2 had 47, a total of 97 participants in the survey.

\subsection{Instrumentation and Data Collection}

The research scale (for questionnaire, see appendix) for this study was developed by Adigüzel (2011, cited in Yasa, 2018), and was adapted and translated into English for use. The sub dimensions of this research: Defining Information Need (defin), Accessing Information (acc), Utilising Information (ut) and Ethical and Legal Regulations in Information Usage (eth). It comprised of twenty-nine closed-ended statements designed on a 5-point Likert scale. 1 (always), 2 (usually), 3 (sometimes), 4 (rarely), 5 (never).

The thirty-three item-questionnaire was distributed to the participants and collected from them after completion. The responses were recorded in MS Excel. The data collected from the participants was analysed by the Nonparametric Mann-Whitney-U and Kruskal-Wallis tests and Descriptive Statistics in the SPSS (Statistical Package for Social Sciences) Program. The descriptive statistics included frequencies and percentages. These were presented in graphical table formats in order to indicate summaries of the collected data. The output received from the participants was compiled into number percentages.

\section{Results}

\subsection{Data Analysis and Findings}

Table 1. Distribution of Gender

\begin{tabular}{lll}
\hline & Frequency & Percent $\%$ \\
\hline male & 21 & 21,6 \\
girl & 76 & 78,4 \\
Total & 97 & 100,0 \\
\hline
\end{tabular}

Table 2. Distribution of University

\begin{tabular}{lll}
\hline & Frequency & Percent \% \\
\hline University 1 & 50 & 51,5 \\
University 2 & 47 & 48,5 \\
Total & 97 & 100,0 \\
\hline
\end{tabular}

Table 3. Distribution of Education Type

\begin{tabular}{lll}
\hline & Frequency & Percent \% \\
\hline Daytime education & 69 & 71,1 \\
Evening education & 28 & 28,9 \\
Total & 97 & 100,0 \\
\hline
\end{tabular}

Table 4. Distribution of Age Groups

\begin{tabular}{lll}
\hline & Frequency & Percent \% \\
\hline $18-20$ & 49 & 50,5 \\
$21-23$ & 43 & 44,3 \\
$24-26$ & 4 & 4,1 \\
$27-29$ & 0 & 0,0 \\
$30-$ over & 1 & 1,0 \\
Total & 97 & 100,0 \\
\hline
\end{tabular}


The difference of mean frequency level between male and female was analysed by a nonparametric Mann-Whitney-U test. The descriptive statistics and test results are given in Table 5 for four sub-dimensions.

Table 5. The Descriptive Statistics and Test Results in Terms of Gender

\begin{tabular}{lllllll}
\hline & gender & $\mathrm{N}$ & Mean & Std. Deviation & Std. Error Mean & Asymp. Sig. (2-tailed) \\
\hline \multirow{2}{*}{ defin } & male & 21 & 2,3810 &, 59749 &, 13038 & 0,389 \\
& girl & 76 & 2,2171 &, 51534 &, 05911 & \\
acc & male & 21 & 2,2294 &, 48670 &, 10621 & 0,525 \\
& girl & 76 & 2,1447 &, 52637 &, 06038 & \\
ut & male & 21 & 2,3333 &, 74655 &, 16291 & 0,541 \\
& girl & 76 & 2,2211 &, 66178 &, 07591 & \\
eth & male & 21 & 2,1619 &, 76058 &, 16597 & 0,188 \\
& girl & 76 & 1,8947 &, 62947 &, 07221 & \\
\hline
\end{tabular}

According to the non-significant $p$-values $(p>\alpha=0,05)$, there is no statistically significant difference between male and female by mean frequency level in any of the four sub-dimensions.

In general, both male and female usually encounter (face) the items of Defining information need (defin), Accessing information (acc), Utilising information (ut) and Ethical and legal regulations (eth) sub-dimensions.

The difference of the mean frequency level between two universities was analysed by the nonparametric Mann-Whitney-U test. The descriptive statistics and test results were given in Table 6 for four sub-dimensions.

Table 6. The Descriptive Statistics and Test Results of Two Universities for 4 Sub-Dimensions

\begin{tabular}{lllllll}
\hline & university & $\mathrm{N}$ & Mean & Std. Deviation & Std. Error Mean & Asymp. Sig. (2-tailed) \\
\hline \multirow{2}{*}{ defin } & University 1 & 50 & 2,1650 &, 52394 &, 07410 & 0,202 \\
& University 2 & 47 & 2,3457 &, 53683 &, 07830 & \\
acc & University 1 & 50 & 2,0455 &, 52248 &, 07389 & $0,019^{*}$ \\
& University 2 & 47 & 2,2882 &, 48525 &, 07078 & \\
\multirow{2}{*}{ ut } & University 1 & 50 & 2,0680 &, 64347 &, 09100 & $0,005^{*}$ \\
& University 2 & 47 & 2,4340 &, 67026 &, 09777 & \\
\multirow{2}{*}{ eth } & University 1 & 50 & 1,8560 &, 54367 &, 07689 & 0,218 \\
& University 2 & 47 & 2,0553 &, 76636 &, 11179 & \\
\hline
\end{tabular}

*: significant at $\alpha=0,05$

Depending on the test results, it can be said that there are statistically significant differences between the two universities by the mean frequency level of Accessing information (acc) and Utilising information (ut) ( $\mathrm{p}<\alpha=0,05$ ).

For the items of Accessing information (acc), the mean frequency level of University 1 is lower than University 2 ( $\chi_{\text {university } 1}=2,0455 \chi_{\text {university } 2}=2,2882$ ). Similarly, for the items of Utilising information (ut), the mean frequency level of University 1 is lower than University 2 ( $\left.\chi_{\text {universityl }}=2,0680 \chi_{\text {university } 2}=2,434 \mathrm{c}\right)$.

The difference of the mean frequency level between two the different educational types was analysed by the A nonparametric Mann-Whitney-U test. The descriptive statistics and test results are given in Table 7 for four sub-dimensions. 1. Education stands for Daytime education, 2. Education stands for Evening Education.

Table 7. The Descriptive Statistics and Test Results in Terms of Education Type

\begin{tabular}{lllllll}
\hline & edutype & $\mathrm{N}$ & Mean & Std. Deviation & Std. Error Mean & Asymp. Sig. (2-tailed) \\
\hline \multirow{2}{*}{ defin } & 1. education & 69 & 2,3243 &, 51997 &, 06260 & $0,038^{*}$ \\
& 2. education & 28 & 2,0759 &, 54043 &, 10213 & \\
\multirow{4}{*}{ utc } & 1. education & 69 & 2,2306 &, 48697 &, 05862 & $0,043^{*}$ \\
& 2. education & 28 & 1,9968 &, 55848 &, 10554 & \\
\multirow{4}{*}{ eth } & 1. education & 69 & 2,3391 &, 66625 &, 08021 & $0,032^{*}$ \\
& 2. education & 28 & 2,0143 &, 66428 &, 12554 & \\
& 1. education & 69 & 2,0493 &, 71653 &, 08626 & $0,031^{*}$ \\
\hline
\end{tabular}

*: significant at $\alpha=0,05$ 
According to the significant $p$-values $(p>\alpha=0,05)$, there were statistically significant differences between the two different educational types by mean frequency levels. For all of the four sub dimensions; related with Defining Information Need (defin), Accessing Information (acc), Utilising Information (ut) and Ethical and Legal Regulations in Information Usage (eth), the mean frequency level of the students who are in Daytime education is higher than the students who are in Evening education.

The difference of mean frequency level between three age-groups was analysed by the nonparametric Kruskal-Wallis test. The descriptive statistics and test results are given in Table 8 for four sub-dimensions.

Table 8. The Descriptive Statistics and Test Results in Terms of Age Groups

\begin{tabular}{lllllll}
\hline & & $\mathrm{N}$ & Mean & Std. Deviation & Std. Error & Asymp. Sig. (2-tailed) \\
\hline defin & $18-20$ & 49 & 2,1837 &, 56140 &, 08020 & \\
& $21-23$ & 43 & 2,3169 &, 52280 &, 07973 & 0,354 \\
& $24-$-over & 5 & 2,3750 &, 31869 &, 14252 & \\
& Total & 97 & 2,2526 &, 53521 &, 05434 & \\
acc & $18-20$ & 49 & 2,1484 &, 52575 &, 07511 & \\
& $21-23$ & 43 & 2,1903 &, 50880 &, 07759 & 0,936 \\
& $24-$-over & 5 & 2,0727 &, 59405 &, 26567 & \\
& Total & 97 & 2,1631 &, 51675 &, 05247 & \\
ut & $18-20$ & 49 & 2,2408 &, 71061 &, 10152 & \\
& $21-23$ & 43 & 2,2837 &, 66937 &, 10208 & 0,594 \\
& $24-$-over & 5 & 1,9600 &, 40988 &, 18330 & \\
& Total & 97 & 2,2454 &, 67854 &, 06890 & \\
eth & $18-20$ & 49 & 1,8816 &, 72677 &, 10382 & \\
& $21-23$ & 43 & 2,0326 &, 55365 &, 08443 & 0,364 \\
& $24-$-over & 5 & 1,9600 &, 96333 &, 43081 & \\
& Total & 97 & 1,9526 &, 66506 &, 06753 & \\
\hline
\end{tabular}

Depending on the test results, it can be said that, there is no statistically significant effect of age on the mean frequency level of any of the four sub-groups $(p>\alpha=0,05)$.

\section{Conclusion and Discussion}

Information literacy helps an individual to be fully informed, capable of deciphering the difference between rhetoric and assertion, and information that is supported by facts and logic (Ercegovac, 2012). It is clear that the process of achieving basic information literacy must be presented by the teachers for the purpose of developing the language skills of the learners. As we live in an information age, this topic is very fashionable and it is not emphasized well for our take. Concerning this, some partially similar research has been completed within the Turkish context, by Akkoyunlu \& Korkut (2008), Ata (2011), and Usluel, Mazman \& Arıkan (2009). These researchers approached the topic from different perspectives such as correlation, self-efficacy, etc. On the other hand, Nizam, Musa \& Wahi (2010) fulfilled a research with only ten students on the related topic and they stated that the result was not satisfactory. Yan-xia (2017) also investigated college English teachers' information literacy and found some problems in the present situation of English teachers' information literacy.

When we analysed the results of our data analysis it was found that, there is no statistically significant difference between males and females by mean frequency level in any of the four sub-dimensions.

It can be said that, there are statistically significant differences between the two universities by the mean frequency level of Accessing information (acc) and Utilising information (ut). For the items Accessing information (acc), the mean frequency level of University 1 is lower than University 2. Similarly, for the items of Utilising information (ut), the mean frequency level of University 1 is lower than University 2.

As for educational type taken, as mentioned previously for all of the four sub dimensions, that is to say that concerning with Defining Information Need (defin), Accessing Information (acc), Utilising Information (ut) and Ethical and Legal Regulations in Information Usage (eth), the mean frequency level of the students who were in Daytime education is higher than the students who were in Evening education. When the mean frequency level of three age-groups (18-20, 21-23, 24 +over) was analysed, it was found that there is no statistically significant effect of age on the mean frequency level of any of the four sub-groups. 
It can be stated that although we compared only the students of English departments in two universities, from the point of view of information literacy awareness in the study, we found some differences. That is, in the Accessing information, Utilising information levels of the English Language Department, the students of two the universities were not equal. The source of these differences may range from social, cultural aspects, the environment where the university is situated, or the learners to teachers' skills or attitudes, etc., within the context of information literacy.

On the other hand, the other outstanding difference was between the students of two education types (Daytime and Evening education). It can be thought that there can be many reasons for that, the reasons may differ. For example; in order to be include Daytime education, students must get higher scores at the university entrance exams, it might be inferred from here that they are more conscious and hard working, or Daytime education period increases the students' motivation positively.

Survey results demostrate that there are some inequalities betwen the two universities in the levels information literacy. In order to shed light on these so called differences and to find likely reasons, some additional detailed studies are needed. Although this study is not detailed and only two state universities were included, we found some inequalities. This research is limited by the survey of two different universities, many more universities can be included for further studies in order to obtain a more general and common conclusion and to develop some general remedies for likely problem areas.

\section{References}

Adıgüzel, A. (2011). Bilgi okuryazarlı̆̆ı ölçeğinin geliştirilmesi. Dicle Üniversitesi Ziya Gökalp Eğitim Fakültesi Dergisi, 17, 15-28.

Akkoyunlu, B., \& Kurbanoglu, S. (2002). Öğretmen Adaylarına Uygulanan Bilgi Okuryazarlığı Programının Etkiliği Ve Bilgi Okuryazarlığı Becerileri İle Bilgisayar Öz-Yeterlik Algısı Arasındaki İlişki. Hacettepe Üniversitesi Eğitim Fakültesi Dergisi, 22(22), 98-105.

Akkoyunlu, B., \& Korkut, E. (2008). Yabancı Dil Öğretmen Adaylarının Bilgi Ve Bilgisayar Okuryazarlık Öz-Yeterlikleri. Hacettepe Üniversitesi Ĕ̈itim Fakültesi Dergisi, 34(34), 178-188.

Alaca, E., \& Önal, İ (2017). Teachers in e-libraries: Research and application. Journal of Teacher Education and Educators, 6(1), 89-116.

Ata, F. (2011). Üniversite Öğrencilerinin Web 2.0 Teknolojilerini Kullanım Durumları ile Bilgi Okuryazarlğğ Öz-Yeterlik Algıları Arasındaki Illişkinin İncelenmesi. Yüksek Lisans Tezi. Dokuz Eylül Üniversitesi, Eğitim Bilimleri Enstitüsü. Retrieved from http://acikerisim.deu.edu.tr/xmlui/handle/12345/7186

Avcı, Ü., \& Seferoğlu, S. S. (2011). Teachers' burnout in the information age: Use of technology and possible actions in preventing burnout [in Turkish]. Mediterranean Journal of Educational Research, 9, 13-26.

Aydın, F. (2010). Ortaöğretim Öğrencilerinin Coğrafya Dersinde Güdülenmelerine Olumsuz Etki Eden Faktörlere İlişkin Görüşleri. Balıkesir Üniversitesi Sosyal Bilimler Enstitüsü Dergisi, 13(24), 31-43.

Aydın, S. (2016). Türkiye 'de yabancı dil öğretmeni yetiştirme: Bir öneri. 4. Ulusal Yabancı Dil Eğitimi Kurultay1, 10-11 Mayıs, Çanakkale 18 Mart Üniversitesi, Eğitim Fakültesi, Çanakkale.

Breivik. P. S., \& Senn, J. A. (1998). Information literacy: Educating children for the 21st Century. (2nd ed.). Washington, DC: National Education Association.

Carr, J. A. (1998). Information Literacy and Teacher Education. ERIC Digest. New York: ERIC Clearinghouse on Information Resources.

Çakmak, T., \& Önal, H. İ. (2013). Bilgi okuryazarlığı becerilerinin kazandırılmasında okul kütüphanecilerinin rolleri ve algıları. Türk Kütüphaneciliği, 27(4), 633-647.

Çelikten, M., Şanal, M., \& Yeni, Y. (2005). Öğretmenlik mesleği ve özellikleri. Erciyes Üniversitesi Sosyal Bilimler Enstitüsü Dergisi, 19(2), 207-237.

Çepni, S. (2007). Araştırma ve Proje Çalı̧̧malarına Giriş. Trabzon: Celepler Matbaacılık.

Demir, M. K., \& Arı, E. (2013). Öğretmen sorunları (Çanakkale ili örneği). Ondokuz Mayıs Üniversitesi Eğitim Fakültesi Dergisi, 32(1), 107-126.

Doyle, C. S. (1994). Information literacy in an information society: A concept for the information age (Research Report No. 372 763). Syracuse, NY: ERIC Clearinghouse on Information and Technology. 
Eğitim Reformu Girişimi. (2013). Fatih projesi eğitimde dönüşüm için bir firsat olabilir mi? Politika analizi ve önerileri. Eğitim Reformu Girişimi (ERG) ve Research Triangle Institute (RTI International).

Ercegovac, Z. (2012). Letting students use Web 2.0 tools to hook one another on reading. Knowledge Quest, 40(3), 36-39.

Etta, F., \& Elder, L. (2005). At the Crossroads: ICT Policymaking in East Africa. Africa: East African Educational Publishers.

European Communities. (2006). Information society and education: Linking European polices. Luxembourg: Office for Official Publication of the European Communities.

Glasser, W. (1996). The Quality School: Managing Students Without Coercion. New York: Harper Collins.

Irgatoğlu, A. (2018). The current system of teacher training programs in one-year preparatory schools of foundation universities in Ankara. Curr Res Educ, 4(1), 20-35.

Kavuncu, E. (2001). Özel ilköğretim okul kütüphanelerinde kullanıcı eğitim programlarının geliştirilmesi. Yayımlanmamış Bilim Uzmanlığı tezi. Hacettepe Üniversitesi, Ankara.

Kurbanoğlu, S., \& Akkoyunlu B. (2001). Öğrencilere bilgi okuryazarlığı becerilerinin kazandırılması üzerine bir çalışma. Hacettepe Üniversitesi Eğitim Bilimleri Fakültesi Dergisi, 21, 81-88.

Kurbanoğlu, S., \& Akkoyunlu, B. (2004). Öğretmenlerin Bilgi Okuryazarlığı ÖzYeterlik İnancı Üzerine Bir Çalışma. Hacettepe Üniversitesi Ĕ̈itim Fakültesi Dergisi, 27, 11-20.

Larson, J., \& Marsh, J. (2005). Making literacy real: Theories and practices for learning and teaching. Thousand Oaks, CA: Sage Publications.

Lowe, G., \& McAuley, J. (2000). Information and Communication Technology Literacy Assessment Framework. Adult Literacy and Lifeskills Survey.

Nizam, A. S., Musa, N. C., \& Wahi, W. (2010). Information Literacy Abilities in ESL Classrooms. AJTLHE, 2(1), $52-65$.

Önal, H. İ, \& Alaca, E. (2017). Vatandaşlık okuryazarlığı çerçevesinde e-Belediye uygulamalarının değerlendirilmesi. Bilgi Dünyast, 18(1), 93-124.

Önal, İ., \& Topçu, Ö. Ş. (2013). Eğitimi gerçekleştirmek: Öğretim programlarında okul kütüphanelerinin yeri. Bilgi Dünyasl, 14(2), 306-328.

Öztürk, H., \& Tağa, T. (2018). Ortaokul öğrencilerinin bir yıllık z-kütüphane deneyimleri: bir durum çalışması. Türk Kütüphaneciliği, 32(1), 7-18.

Qin, M. J., \& He, G. K. (2009). Discussion on the Connotation of College English Teachers' Information Literacy. Foreign Language World, 5, 18-25.

Uçak, N. Ö., \& Topçu, Ö. Ş. (2012). Günlük yaşamda bilgi gereksinimi ve halk kütüphaneleri. 2. Halk Kütüphaneciliği Sempozyumu: Değişen Dünyada Halk Kütüphaneleri 9-12 Mayıs 2012, Bodrum: Bildiriler, Posterler ve Çalıştay Raporları içinde (s. 120-134). Ankara: Kültür ve Turizm Bakanlığı.

UNESCO/ United Nations Educational, Scientific and Cultural Organisation. (2006). Using ICT to develop literacy. Bangkok: UNESCO.

Usluel, Y. K., Mazman, S. G., \& Arikan, A. (2009). Prospective teachers' awareness of collaborative web 2.0 tools. In The IADIS International Conference www/Internet 2009, 19-22.

Uzuegbu, C. P. (2014). Introduction to information literacy. In U. Arua, C.P. Uzuegbu \& A.D. Ugah (Eds.), Information literacy education for tertiary institutions (pp. 1-18). Umuahia, Nigeria: Zeh Communications.

Wilkinson, C. (2012). Transforming information literacy programs: Intersecting frontiers of self, library culture, and campus community. Chicago, IL: ACRL Publications in Librarianship.

Wlodkowski, R. J. (1999). Motivation and Diversity: A Framework for Teaching. New Directions for Teaching and Learning, 78, 7-9.

Yan-xia, D. (2017). Research on College English Teachers' Information Literacy inInformation Environment. English Language Teaching, 10(11), 37-43. https://doi.org/10.5539/elt.v10n11p37 
Yaşa, H. D. (2018). Öğretmen Adaylarinin Yaşam Boyu Öğrenme Ĕgilimleri ile Bilgi Okuryazarliği Becerileri Arasindaki İlişkinin Değerlendirilmesi. Yayınlanmamış Yüksek Lisans Tezi Bartin Üniversitesi.

Yavuzalp, N., Gürer, M. D., Curaoğlu, O., Durmuş, S., Akayoğlu, S., Bahar M., .... Tekinarslan, E. (2015). FATIH Project in Turkey: A Case Analysis. International Journal of Research in E-learning, 1(1), 117-127.

Zurkowski, P. G. (1974). The Information Service Environment Relationships and Priorities. Related Paper No. 5.

Appendix

\section{Information Literacy Questionnaire}

\begin{tabular}{|c|c|c|c|c|c|c|}
\hline & & 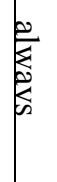 & 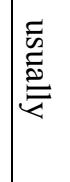 & 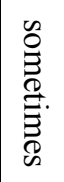 & 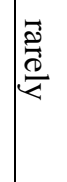 & 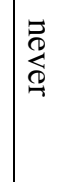 \\
\hline \multicolumn{2}{|c|}{ Defining Information Need } & & & & & \\
\hline 1 & Determining the types and areas of information sources & & & & & \\
\hline 2 & Configuring information requirement by sharing it with others & & & & & \\
\hline 3 & Knowing where to find the information required & & & & & \\
\hline 4 & Knowing the types and the importance of information sources & & & & & \\
\hline 5 & Defining information requirement & & & & & \\
\hline 6 & $\begin{array}{l}\text { Knowing the fundamental concepts related to the information } \\
\text { required }\end{array}$ & & & & & \\
\hline 7 & $\begin{array}{l}\text { Knowing how information is organised on the basis of its } \\
\text { fundamental properties }\end{array}$ & & & & & \\
\hline 8 & $\begin{array}{l}\text { Regularly reviewing the scope and the structure of information } \\
\text { requirement }\end{array}$ & & & & & \\
\hline \multicolumn{7}{|c|}{ Accessing Information } \\
\hline 9 & $\begin{array}{l}\text { Summarising the basic ideas by examining the information sources } \\
\text { obtained. }\end{array}$ & & & & & \\
\hline 10 & $\begin{array}{l}\text { Understanding and evaluating the different perspectives in } \\
\text { information sources }\end{array}$ & & & & & \\
\hline 11 & Taking the evaluation criteria regarding web sources into account & & & & & \\
\hline 12 & Categorising the information obtained on the basis of specific criteria & & & & & \\
\hline 13 & $\begin{array}{l}\text { Authentically re-stating the information obtained from the sources by } \\
\text { correlating it with the prior information }\end{array}$ & & & & & \\
\hline
\end{tabular}




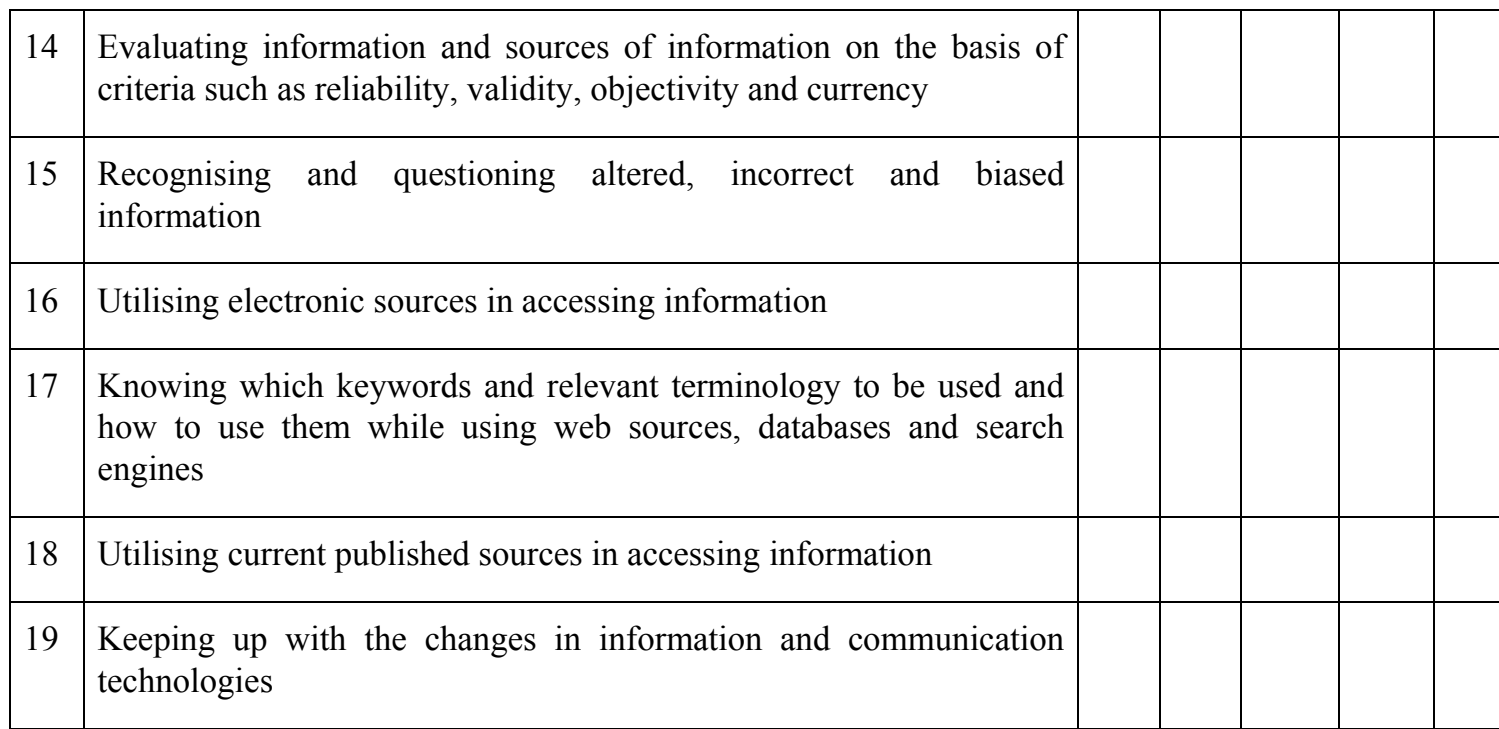

\section{Utilising Information}

20 Using the information obtained in solving problems by organising it systematically

21 Comparing and integrating prior and new information in order to determine the fundamental properties, importance and discrepancies pertaining to information

22 Properly saving and organising all information excerpts in order to be able to access the sources again when necessary

23 Presenting the results of the information by interpreting the information obtained

24 Determining the relation between the concepts and retrieved results on the basis of the information accessed

\section{Ethical and Legal Regulations in Information Usage}

25 Taking the freedom of thought and expression in obtaining information

26 Accessing and using information legally

27 Completely and correctly indicating the original sources of the information used

28 Taking the personal rights and security issues in printed sources and electronic platforms into account

29 Taking the privacy and security issues regarding the information to be used into account 